軸受と同様であるが上半分には中央の油溝がない。

5）シリンダカバー AS形は4弁式になっているほか は，特に形状などは大きな差異はない.シリンダカバー内面 は 2 弁式の場合之同様に二重壁構造である. 冷却水はシリ ンダライナ支持環から 4 か所取り入れ均等に冷却される.

6）ピストン ピストンはアルミ合金製でコイル状 の冷却管を鋳ぐるみにしたもので，第 1 ，第 2 リングの みぞ部分は鋼製環が鋳ぐるみになっている.

ピストンリングは特殊鋳鉄で, コンプレッションリン グは 3 本，オイルリング 2 本で，いずれもピストンピン より上方にある・ピストンピンはフローティング式で両 端はスプリングリングで止められている.

7）シリンダライナ 耐摩耗性のよい特殊鋳鉄製で, 上部に冷却水ジャケット金物をはさんで，架構にはめ合 わせてある。下部は 2 本の○リングにより, 冷却水のシ ールを図っている.

冷却水はライナ下部の方から流入し, 架構と共に構成 された冷却水室を経て，上方の冷却水ジャケット金物よ り4 加所分れてシリンダカバーに流れるため, ライナ全 面が均等に冷却される.

8） カム軸 カム軸はニッケル・クロム・モリブデン 鋼製で, 各シリンダごとに分割され，リーマボルトによ って結合される. 力ムと力ム軸は一体のあので, シリンダ 数の分のカム軸を接続すればよいので，極めて便利である.

カム軸の駆動は，機関後部側のクランク軸付歯車から 2 段の中間歯車を介して行なわれる.

以上, 簡単ではあるが, これで主要部構造の説明を終え させていただきたい，掲載した縦断面図及び横断面図をご 覧いただけば大半の構造はご理解いただけるすのと思う.

\section{5 阪神内燃機関工業(株)*}

\section{孝橋謙 一**}

\section{1. まえがき}

現在の機械設備, 運転設備などの生産設備面から見る 之, 当社では, シリンダ径 300〜 $550 \mathrm{~mm}$ の低速機関が最
も適当な機種であり，採算面からあこのクラスの機関が 望ましい.

しかし, シリンダ径 $300 \mathrm{~mm}$ 以下の機関む古くから手 がけており，表 1.5.10ごとく，シリンダ径で 3 種類, 機種にして 8 機種の機関を製作している.

最近, 近海船の減少に伴い, 当社の中で大形に属する 機関の需要が激減し, 一方, 200 海里問題が発生して以 来, 漁船に拈いても遠洋漁業の衰退により, 小形化の傾 向が顕著となり, $300 \mathrm{~mm}$ 以下の機種の占める比重が増加 しつつある。

\section{2. 機関の概要}

表 1.5 .1 亿機関の主要目を, 表 1.5 .2 亿その主要外形 寸法を示す.

2.16 L UD 24 形と6 L UD26 形両者は, ほ ぼ相似設計の機関である．乙れら機関の特徵は，当社独 得の 3 弁式シリンダカバを採用している点にある. 当社 の 3 弁式は弁箱付き排気弁 1 個之直付け吸気弁 2 個上り 成り，燃料弁をわずかにシリンダ中心より偏移させるこ とにより, 排気弁の弁面積を増大させ, 一方, 吸気弁は 2 個使用することによって，その弁面積は排気弁のそれ よりも更に大きくしている，乙の構造によって，通常の 4 弁式機関之同程度の性能を得, しかも, 排気弁の抜出 し点検などの取扱いを容易にしたことを特徴としている.

クランク軸は RR 鍛造を採用し，ピストン冠や連接棒 は型鍛造, メタル類は力ム軸受も含めてすべて薄肉完成 メタルとし，ピストンは中支え形の構造で冷却方式はシ エーカータイプを採用している. 小形であるため, シリ ンダと架構は一体形の鋳鉄構造とし, 支柱ボルトは使用 していない.

2.26 L U 28 形吸気弁・排気弁各1個を有する 普通の 2 弁式機関である. 弁の大きさは吸・排と屯同一 であるが，排気弁は弁箱付き，吸気弁は直付けであり， 燃料弁はわずかに偏心させている. 吸排気管はいずれも 機関の後側に配置し, このクラス以上の大形機関は台板・ 架構・シリンダの三つに分割し, 支柱ボルト構造として いる.

表 1.5.1 機関の主要目

\begin{tabular}{|c|c|c|c|c|c|c|c|c|c|c|}
\hline 機関形式 & $\begin{array}{c}\text { シリンダ径 } \\
\mathrm{mm}\end{array}$ & $\begin{array}{c}\text { ストローク } \\
\mathrm{mm}\end{array}$ & $\begin{array}{c}\text { 回転数 } \\
\mathrm{rpm}\end{array}$ & $\begin{array}{c}\text { 出 力 } \\
\text { PS }\end{array}$ & シリンダ数 & $\begin{array}{c}\text { 正味平均 } \\
\text { 有効圧力 } \\
P_{\mathrm{me}} \\
\mathrm{kg} / \mathrm{cm}^{2} \\
\end{array}$ & $\begin{array}{c}ヒ^{0} \text { スト } \\
\text { 速 }{ }^{\text {度 }} \\
\mathrm{m} / \mathrm{s}\end{array}$ & $\begin{array}{c}\text { シリンダ内 } \\
\text { 最大圧力 } \\
\mathrm{kg} / \mathrm{cm}^{2}\end{array}$ & $\begin{array}{l}\text { 出力率 } \\
P_{\mathrm{me}} \times C\end{array}$ & $\begin{array}{c}\text { 重 量 } \\
\mathrm{t}\end{array}$ \\
\hline 6LUD 24 & 240 & 410 & 400 & 900 & 6 & 18.20 & 5.47 & 105 & 99.6 & 12.5 \\
\hline 6LUD26 & 260 & 440 & 400 & 1,100 & 6 & 17.66 & 5.87 & 100 & 103.7 & 14.5 \\
\hline 6LU28 & 280 & 440 & 395 & 1,200 & 6 & 16.82 & 5.79 & 105 & 97.4 & 17.0 \\
\hline 6LUN28A & 280 & 480 & 375 & 1,350 & 6 & 18.27 & 6.00 & 110 & 109.6 & 18.0 \\
\hline 6LUN28 & 280 & 480 & 395 & 1,600 & 6 & 20.55 & 6.32 & 110 & 129.9 & 18.1 \\
\hline $6 \mathrm{~L} 24 \mathrm{SH}$ & 240 & 400 & 400 & 650 & 6 & 13.47 & 5.33 & 78 & 71.8 & 9.2 \\
\hline $6 \mathrm{~L} 26 \mathrm{BSH}$ & 260 & 400 & 400 & 750 & 6 & 13.25 & 5.33 & 78 & 70.6 & 11.7 \\
\hline $6 \mathrm{MUH} 28$ & 280 & 340 & 630 & 1,700 & 6 & 20.14 & 7.14 & 110 & 143.8 & 15.0 \\
\hline
\end{tabular}

*原稿受付 昭和 53 年 10 月 27 日

**正会員阪神内燃機工業（株）（明石市貴崎 5-8-70） 
表 1.5.2 機関の主要外形寸法
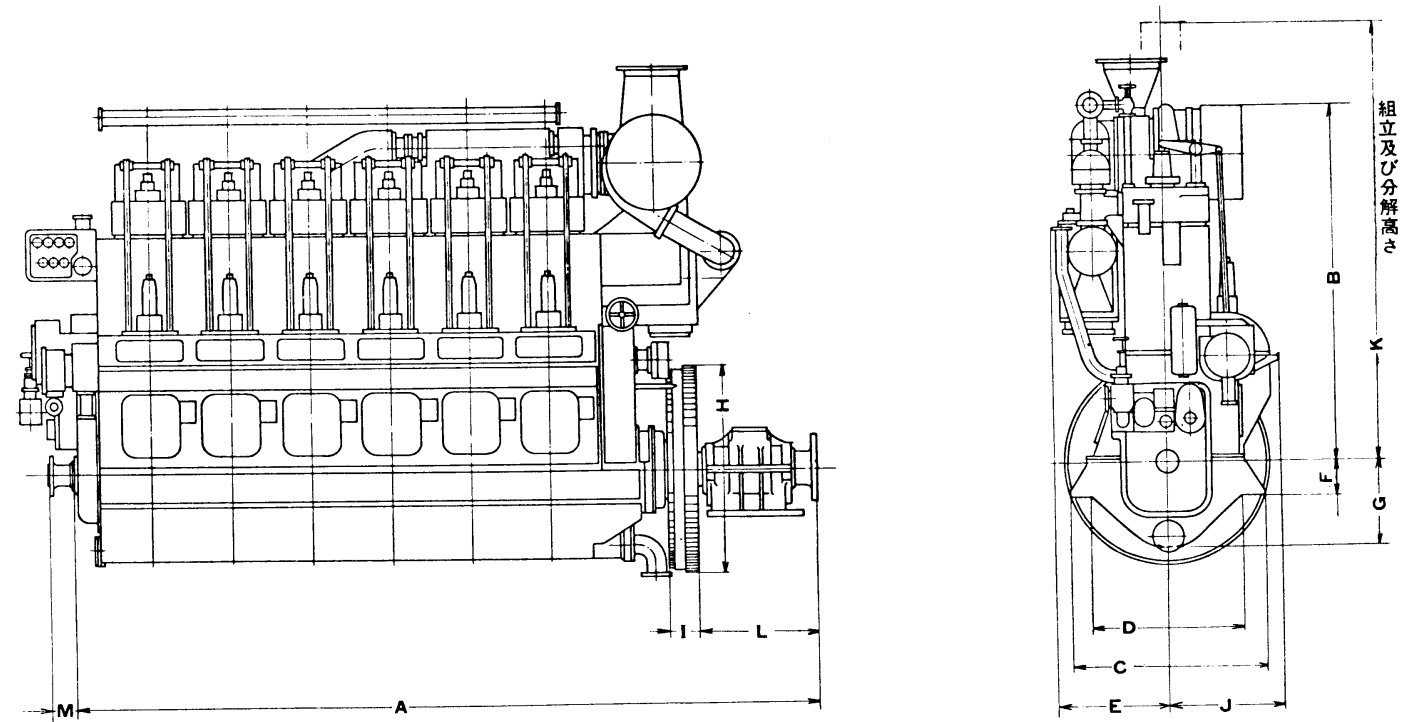

\begin{tabular}{|c|c|c|c|c|c|c|c|c|c|c|c|c|c|}
\hline 機関形式 寸法 & A & B & C & D & E & F & G & H & I & J & K & L & M \\
\hline 6LUD24 & 3,853 & 1,867 & 1,020 & 790 & 793 & 180 & 670 & 1,100 & 270 & 645 & 2,194 & 610 & 237 \\
\hline 6LUD26 & 3,992 & 1,973 & 1,120 & 880 & 848 & 210 & 680 & 1,100 & 270 & 848 & 2,323 & 610 & 238 \\
\hline 6LU28 & 4,325 & 2,155 & 1,120 & 880 & 843 & 210 & 710 & 1,150 & 300 & 750 & 2,355 & 610 & 270 \\
\hline 6LUN28A & 4,340 & 2,190 & 1,190 & 950 & 863 & 210 & 730 & 1,150 & 300 & 855 & 2,380 & 610 & 270 \\
\hline 6LUN28 & 4,399 & 2,190 & 1,190 & 950 & 863 & 210 & 730 & 1,150 & 300 & 855 & 2,380 & 669 & 270 \\
\hline 6L 24SH & 3,592 & 1,861 & 1,020 & 800 & 850 & 150 & 600 & 980 & 255 & 605 & 2,125 & 1,470 & 248 \\
\hline 6L 26BSH & 3,885 & 1,896 & 1,080 & 860 & 860 & 150 & 550 & 1,060 & 235 & 735 & 2,165 & 520 & 230 \\
\hline 6 MUH28 & 5,407 & 1,960 & 1,110 & 820 & 880 & 210 & 660 & 1,050 & 130 & 870 & 2,078 & 1,840 & 268 \\
\hline
\end{tabular}

2.3. 6 L UN 28 形 現在の当社の中では最高の出 力率を持った機関の一つである. 図 1.5.1 亿機関の組立 断面図を，図 1.5 .2 亿機関の代表性能を示す. シリンダ 内最高圧力を $110 \mathrm{~kg} / \mathrm{cm}^{2}$ に高め, 乙れに伴ってクラン ク軸の寸法, シリンダライナの肉厚を増すなど，各部の 機械的強度を高め, 軸受面積を増大した。 また，シリン ダカバは吸排気弁とあ直付けの 4 弁式であるが，図 1.5 . 3 のごとく独特のセミサイアミーズ形とすることによっ て，2 個の吸・排気弁をそれぞれ流れに対し対称形に近 く配置し, しかも, 動弁装置は最も簡単なブリッジ方式 を採用している. また，燃料噴射系統の設計には十分の 考慮を払い, 特に燃料力么は減速力么を採用して, 噴射 の初期の特性を改善した.

過給機は圧力比の高い領域において効率の高いVTR一 251 形を装備し, 吸気管はいわゆるフロントサクション 形の配置とした。 また, 空気冷却器も改造して, 前面面 積と奥行きとの関係を高過給機関に適するような形に改 めた.

この機関の圧縮比をわずかに低下させ，当社が開発し た吸気加熱装置を備えるととにより，機関構造を変更す るととなしに， 6 シリンダ 1,700 馬力 (平均有効圧力 22 $\left.\mathrm{kg} / \mathrm{cm}^{2}\right)$ まで出力を上昇することができた，また，圧縮 比を低下させ， 2 段過給を行なうことによって，6シリ ンダで 2,050 馬力 (平均有効圧力 $26 \mathrm{~kg} / \mathrm{cm}^{2}$ ) まで出力上 昇できることを確認した。乙れらはいずれもシリンダ内 最高压力は現状と同じく $110 \mathrm{~kg} / \mathrm{cm}^{2}$ におさえており，ま た, シリンダ出口排気温度は $400^{\circ} \mathrm{C}$ 以下であって, 機械 的ならびに熱的負荷は現状の機関とほとんど差異のない ことを確認している. 表 1.5 .3 にこれらの機関の要目を 示す.

\subsection{UN 28 A 形 6 LUN28 形機関のシリン} ダカバーのみを改造して，2 弁式とした機関である. セミ サイアミーズ形の空気の流れの利点を生かし，流れの経 路はそのままで 2 弁とし, 吸気弁は直付けであるが排気 弁は弁箱付きとして取扱いを容易にした．乙の弁配列は 有効な模様で, 運転結果は予想以上の好性能を示してい るので, 近く, 更に, 販売出力を高める予定でいる.

2.5 6L 24SH，6L26BSH 両者は古くから 作られてきた機関に部分的な改造を加えた機関である. ピストン冷却を行なっておらず，且つ，シリンダ内最高 圧力も $78 \mathrm{~kg} / \mathrm{cm}^{2}$ と低く, これ以上出力を上げるととは 困難であるが, 構造・取扱いが簡単なととと, 古くから 


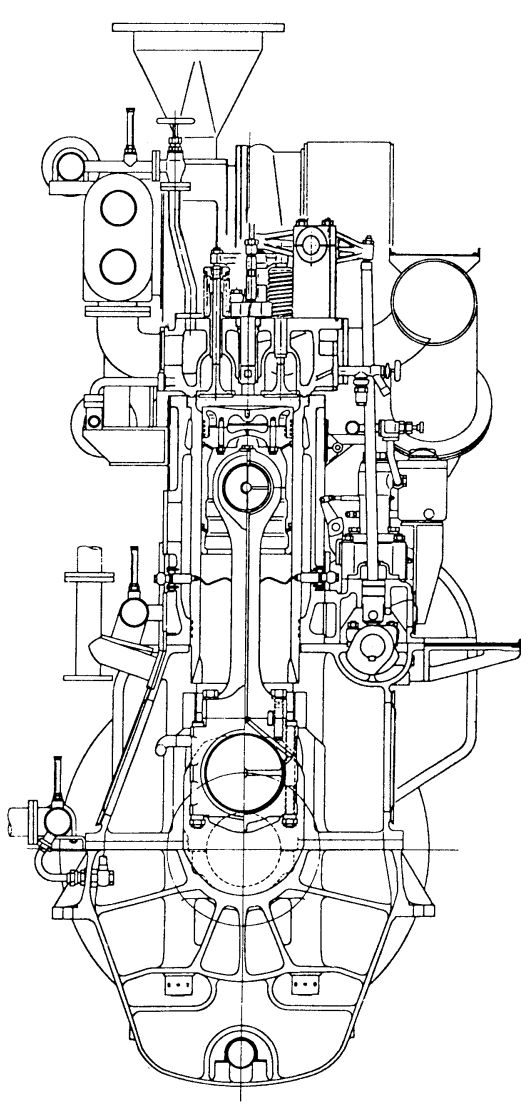

㘡 1.5.16 LUN28 形の組立断面図
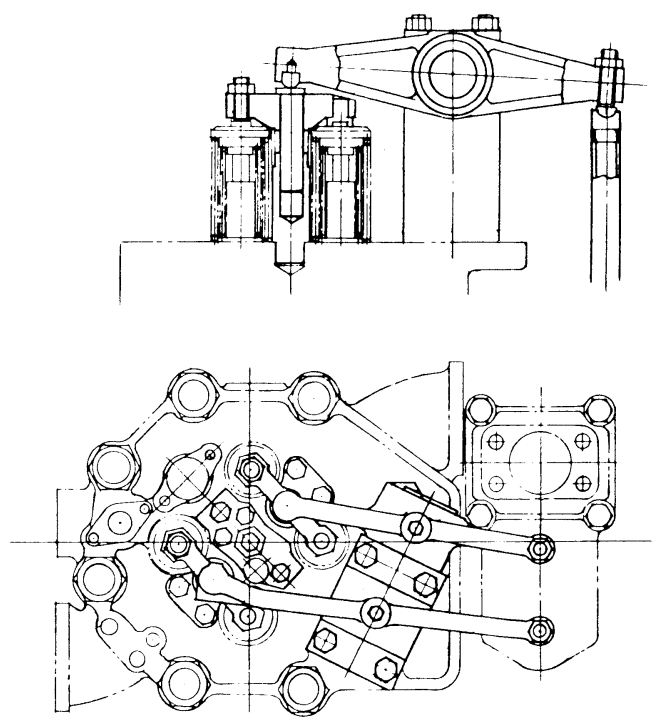

図 1.5.36LUN28 形シリンダカバ組立図

表 1.5.36LUN 28 形のシリーズ機関

\begin{tabular}{|c|c|c|c|c|}
\hline & & 6 LUN 28 & 6LUN28F & \multirow{2}{*}{$\begin{array}{c}6 \text { LUN28ZF } \\
\text { 低压縮 比 } \\
\text { 二段過給 }\end{array}$} \\
\hline & & 形 & $\begin{array}{l}\text { 低压縮 比 } \\
\text { 機 }\end{array}$ & \\
\hline $\begin{array}{l}\text { シリンダ径×ストローク } \\
\text { シリン ダ 数 } \\
\text { 回 転 } \\
\text { 平均ピストン速度 } \\
\text { シリンダ内最高压力 }\end{array}$ & $\begin{array}{c}\mathrm{mm} \\
\mathrm{rpm} \\
\mathrm{m} / \mathrm{s} \\
\mathrm{kg} / \mathrm{cm}^{2} \\
\end{array}$ & \multicolumn{3}{|c|}{$\begin{array}{c}280 \times 480 \\
6 \\
395 \\
6.32 \\
110 \\
\end{array}$} \\
\hline $\begin{array}{lll}\text { 出 } & & \text { 力 } \\
\text { 平 均 有効 圧 吕 } \\
\text { 縮 }\end{array}$ & $\begin{array}{c}\mathrm{PS} \\
\mathrm{kg} / \mathrm{cm}^{2}\end{array}$ & $\begin{array}{c}1,600 \\
20.55 \\
12.1\end{array}$ & $\begin{array}{c}1,700 \\
21.84 \\
11.6\end{array}$ & $\begin{array}{c}2,050 \\
26.33 \\
9.6\end{array}$ \\
\hline 給 & & VTR251 & VTR 251 & $\begin{array}{l}\text { VTR } 251 \\
\text { V'TR } 321 \\
\end{array}$ \\
\hline
\end{tabular}

広く普及しているために，いまだに需要が絶えない。

2.6 6 MUH 28 形 中速機関で二段噴射燃焼方 式を利用した高過給機関である. 昭和 43〜 44 年度の日 本舶用機器開発協会の補助事業として開発した.

二段噴射燃焼方式は，シリンダ内最高圧力の上昇を少 しでも少なくするために開発した方式である。すなわち， 予燃炡室機関のごとく主燃焼室のほかに副燃焼室を設け， 副燃焼室に燃料の副噴射系統を配置し，副噴射の噴射時 期を主噴射のそれより屯おそくして，二段噴射を行なう 方式である。

この方式によると, 主噴射による燃料が着火し, 燃焼 を開始する時期に，副然焼室の噴気孔より噴出するガス 流により，燃焼室内がかくはん混合されて燃焼が促進さ れる. そのため, 主噴射の開始時期在通常の場合に比し おくらせても，アフタバーニングが短縮されるので，燃 焼時間が短くなり，機関性能を悪化させずにシリンダ内 最高压力を低下させることぶできる６ 平均有効圧力は $20 \mathrm{~kg} / \mathrm{cm}^{2}$ を越えているにあかかわらず, シリンダ内最高圧力は $110 \mathrm{~kg} / \mathrm{cm}^{2}$ におさまっている.

困 1.5.26 LUN28 形 (4 弁式1,600 PS)の機関性能 


\section{3.あとがき}

以上，当社で製作しているシリンダ径 $300 \mathrm{~mm}$ 以下の 小形機関につきその特徽を説明した. これら機関の 1 号 機の出荷時期之現在までの出荷台数は表 1.5.4 のとおり である.最近，海運造船界は未兽有の不況に見舞われて いる. 乙の需要の減退のさ中で御使用載く機関は，十分 の実績と信頼性を有し，従来以上に需要者の御要望を満 たすあのでなければならないことを痛感するものである。

表 1.5.4 機関出荷台数

\begin{tabular}{|l|c|c|r|r|}
\hline & 1 号機出荷時期 & 合計台数 & 貨物船 & 漁 船 \\
\hline 6L 24 SH & 45 年 4 月 & 42 & 16 & 26 \\
6L 26BSH & 47 年 3 月 & 90 & 53 & 37 \\
6LUD24 & 51 年 11 月 & 17 & 1 & 16 \\
6LUD26 & 47 年 2 月 & 108 & 38 & 70 \\
6LU28 & 44 年 7 月 & 229 & 143 & 86 \\
6LUN28A & 53 年 8 月 & 1 & 0 & 1 \\
6LUN28 & 46 年 4 月 & 81 & 19 & 62 \\
6 MUH28 & 46 年 12月 & 8 & 7 & 1 \\
8MUH28 & 52 年 5 月 & 1 & 1 & 0 \\
\hline
\end{tabular}

\section{6 ヤンマーディーゼル(株)*}

桂田史郎 ${ }^{* *}$ 氏家秀夫**

\section{1. まえがき}

漁船の高速化は，乙乙数年来変ら傾向であり，船体 のFRP化が進み，50〜99トン級に及んでいる．乙れと 共にとう載機関に対しても，小形軽量化が要求され，特 に沿海，近海域を漁場とする軽中作業船において，その 傾向が著しい，近年， 200 海里漁業専管水域問題に直面 している日本では, この沿海, 近海漁場の重要性がクロー ズアップされ，漁船の性能向上に期するところが大きい.

また, 昭和 48 年の石油ショックに端を発した, 省工 ネルギの要求から, 燃料, 潤滑油の経済性が強く要求さ れると共に，公害対策として，低騒音，低振動に対する 要求屯ますます厳しくなってきている。

当社では， $8 \mathrm{PS}$ か $3,000 \mathrm{PS}$ までの, 船用主機, 補 機関を市場に提供しているが，乙うした市場の要求に こたえるへくく, 機関の軽量小形化, 低燃料消費, 低潤滑 油消費化を進めると共に, 低公害化, 長期無解放運転に 対する努力を続けている。乙こに紹介する 6 LAA-DT 形屯, 軽量エンジンシリーズの一つとして, 昨年発売以 来, 各地で使用され好評を得ており, 最近の市場二ーズ に十分こたえ得るあの之思う。

\section{2. 設計のねらい}

$6 \mathrm{LAA}$-DT形機関は, 軽量体質の 6 シリンダ, 直接 噴射式, 高過給機関で, その設計のねらいは, FRP 船の

* 原稿受付 昭和 53年 11 月 24 日

**正会員 ヤンマーディーゼル(株)(大阪市北区茶屋町 1-32)
特徵である軽量, 高速にマッチした軽量, 高性能化之, 船用機関としてか酷な作業条件に耐える耐久性，信頼性 の確保にある.

（1）軽量, 高出力でコンパクトであり, しかも, 舶用 機関として十分な操作性，耐久性を有する。

（2）燃料，潤滑油の消費が少なく，軽油，A重油いずれ の燃料屯使用可能な省資源形で，維持費の安い機関とする.

（3）漁船機関として必要な低いアイドル回転速度と長時 間の低力運䎐を可能とし, 高負荷運転を屯含め, 各種の操 業パターンに対応できるフレキシビリティを有する.

（4）各種漁労装置とのシステム化を考慮し, 前部駆動 装置を機関に装備すると共に，発電機セットを考慮し， 減速逆転機, 発電機のいずれも直結可能なマウンティン グ方式とする.

（5）減速逆転機は歯車及び軸継手の軸締結部を，当社 独自のキーレス油圧ばめ構造とし, 軽量, コンパクト化 を困る。

\section{3. 主要諸元}

主要諸元を表 1.6 .1 亿，機関外観を図 1.6 .1 亿示す.

表 1.6.1 6 LAA-DT形主要諸元

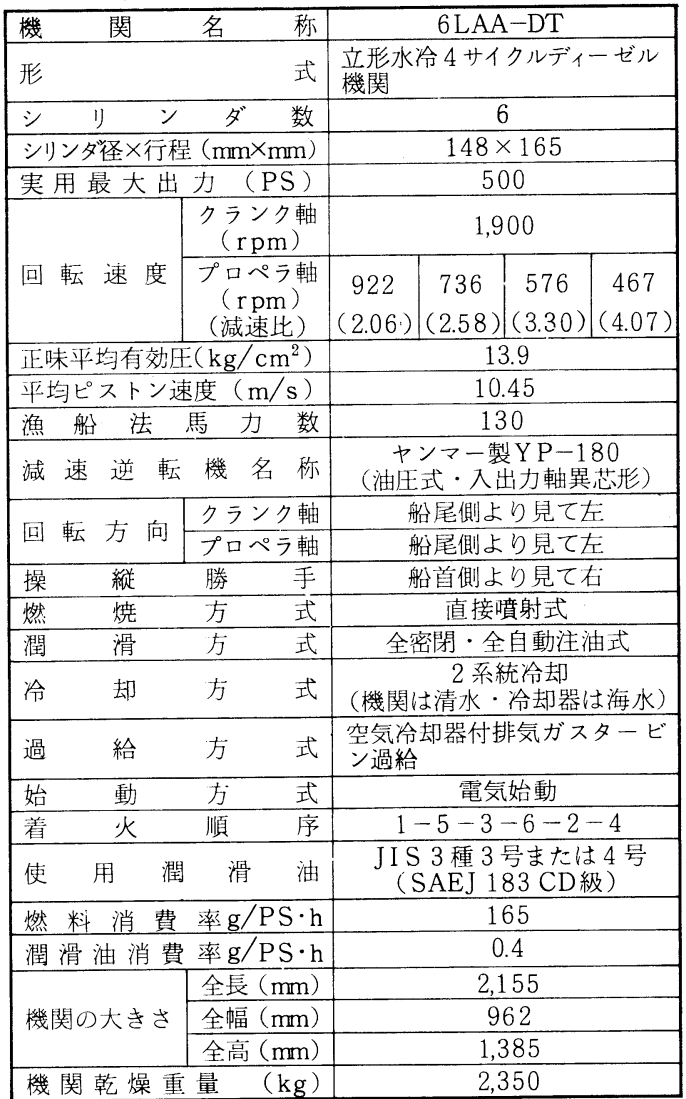

借考 1 . 機関乾燥重量は, 減速逆転機及び潤滑油冷却器他付 属品を含む?

2. 燃料消費率は, 減速逆転機付で燃料油の低位発熱量 $10,200 \mathrm{kcal} / \mathrm{kg}$ の場合を示す 